\title{
Studi Epidemiologi \\ Perkembangan Prehipertensi Menjadi Normotensi, Tetap Prehipertensi, Hipertensi Stage I dan Stage II Setelah 10 Tahun
}

\author{
Haidar Alatas ${ }^{1}$ \\ ${ }^{1}$ Gadjah Mada University Yogyakarta Indonesia, Internal Medicine, Nephrology-Hypertension Departement, RSUD \\ Banyumas, Mlati Study Group \\ Email : haidar_papdi@yahoo.com
}

\begin{abstract}
Individual with a systolic BP of 120 to $139 \mathrm{mmHg}$ or diastolic $\mathrm{BP}$ of 80 to $89 \mathrm{mmHg}$ should be considered as prehypertensive and require health-promoting lifestyle modifications to prevent CVD. After four years, $40 \%$ of prehypertension that is not managed properly becomes serious hypertension. Approximately $31-37 \%$ of US adults are prehypertensive, is associated with 3-fold greater likelihood of developing hypertension and roughly twice the cardiovascular events. What is the progress of prehypertension after 10 years in rural populations? Will it be normal (normotensive), still prehypertension, become stage I hypertension or stage II hypertension. Epidemiological studies were conducted in Mlati Village, Sleman, Yogyakarta. From the prehypertension subject data as many as 4,091 who were on the computer, after 10 years were selected who were still aged 30-59 years, were willing to take further research and then do interviews and blood pressure checks. The data obtained was analyzed. Of the 743 subjects now aged 30-59 years, who had prehypertension ten years ago, their blood pressure became normal as many as 183 (25\%), still prehypertension was $328(44 \%)$, became stage I hypertension as much as $152(20 \%)$ and became hypertensive stage II as many as $80(11 \%)$.
\end{abstract}

Key word : progress, prehypertension, hypertension

\section{Abstrak}

Prehipertensi menurut JNC 7 adalah tekanan darah 120-139/80-89 mmHg. Dalam 4 tahun, $40 \%$ prehipertensi dilaporkan akan menjadi hipertensi yang serius bila tidak dikelola dengan baik. Sekitar 31-37\% populasi di Amerika Serikat dewasa merupakan penyandang prehipertensi dan berhubungan dengan kecenderungan tiga kali lipat untuk mengalami hipertensi dan dua kali lipat untuk mengalami kejadian kardiovaskular dibanding orang dengan tekanan darah normal. Bagaimana perkembangan prehipertensi setelah 10 tahun pada populasi daerah pedesaan? Apakah akan menjadi normal (normotensi), tetap prehipertensi, menjadi hipertensi stage I atau hipertensi stage II. Dilakukan studi epidemiologi di Desa Mlati, Sleman, Yogyakarta. Dari data subyek prehipertensi sebanyak 4.091 yang ada di komputer, setelah 10 tahun dipilih yang masih berusia 30-59 tahun, bersedia mengikuti penelitian lanjutan kemudian dilakukan wawancara dan pemeriksaan tekanan darah. Data yang didapatkan dianalisis. Dari 743 subyek sekarang berusia 30-59 tahun, yang sepuluh tahun lalu prehipertensi, didapatkan tekanan darahnya menjadi normal sebanyak $183(25 \%)$, tetap prehipertensi sebanyak 328 (44\%), menjadi hipertensi stage I sebanyak $152(20 \%)$ dan menjadi hipertensi stage II sebanyak $80(11 \%)$.

Kata kunci : perkembangan, prehipertensi, hipertensi 


\section{PENDAHULUAN}

Prehipertensi

merupakan

pengelompokan besarnya tekanan darah yang tidak termasuk normal namun bukan hipertensi, atau dinamakan juga borderline hipertensi 1. Prehipertensi menurut Joint National Committee (JNC 7) adalah tekanan darah sistolik 120-139 $\mathrm{mmHg}$ dan atau tekanan darah diastolik $80-89 \mathrm{mmHg}^{2}$. Dalam 4 tahun, $40 \%$ prehipertensi dilaporkan akan menjadi hipertensi yang serius bila tidak dikelola dengan baik ${ }^{3}$. Begitu pentingnya prehipertensi maka ACC/AHA 2017 mengelompokkannya menjadi hipertensi stage I 4 . Prehipertensi saat ini menjadi masalah kesehatan yang penting. Sekitar 31-37\% populasi di Amerika Serikat dewasa merupakan penyandang prehipertensi dan berhubungan dengan kecenderungan 3 kali lipat untuk mengalami hipertensi dan 2 kali lipat untuk mengalami kejadian kardiovaskular dibanding orang dengan tekanan darah normal ${ }^{5}$. Studi populasi di Jepang menunjukkan bahwa subyek dengan prehipertensi akan meningkatkan risiko kardiovaskular terutama setelah berkembang menjadi hipertensi ${ }^{6}$.

Bagaimana perkembangan prehipertensi setelah 10 tahun pada populasi daerah pedesaan? Apakah akan menjadi normal (normotensi), tetap prehipertensi, menjadi hipertensi stage I atau hipertensi stage II.
Dilakukan studi epidemiologi di Desa Mlati, Sleman, Yogyakarta.

\section{METODE}

Dilakukan studi epidemiologi 10 tahun yang lalu dengan stratifikasi pengambilan sampel acak dari 12.073 peserta. Subjek penelitian berusia 30-59 tahun dari setiap kelompok yang dilakukan secara acak. Dari 7.695 orang, sebanyak 1.522 orang $(19,7 \%)$ subjek hipertensi terdiri dari hipertensi stage I sebanyak 15,4\% (1.188); hipertensi stage II sebanyak 4,3\% (334), prehipertensi 53,2\% (4.091) dan normotensi sebanyak 27,1\% (2.082). Dari data subyek prehipertensi sebanyak 4.091 yang ada di komputer, setelah 10 tahun dipilih yang masih berusia 30-59 tahun, bersedia mengikuti penelitian lanjutan kemudian dilakukan wawancara dan pemeriksaan tekanan darah. Data yang didapatkan dianalisis.

\section{HASIL}

Dari data subyek prehipertensi sebanyak 4.091 yang ada di komputer, setelah 10 tahun dipilih yang masih berusia 30-59 tahun, bersedia mengikuti penelitian lanjutan kemudian dilakukan wawancara dan pemeriksaan tekanan darah didapatkan subyek sebanyak 743. Dari 743 subyek sekarang berusia 30-59 tahun, yang sepuluh tahun lalu prehipertensi, didapatkan tekanan darahnya menjadi normal sebanyak 183 
(25\%), tetap prehipertensi sebanyak 328 (44\%), menjadi hipertensi stage I sebanyak 152 (20\%) dan menjadi hipertensi stage II sebanyak 80 (11\%) (Tabel 1).

\section{DISKUSI}

Prehipertensi saat ini merupakan masalah kesehatan yang penting. Sekitar 3137\% populasi di Amerika Serikat dewasa merupakan kelompok prehipertensi. Berdasarkan The Third National Health and Nutrition Examination Survey (NHANES-III) tahun 1999-2000, diketahui bahwa prevalensi prehipertensi sekitar $31 \%$ tanpa adanya perbedaan ras dan etnis ${ }^{7}$. Studi epidemiologi di Mlati, Sleman, Yogyakarta didapatkan $4.091(53,2 \%)$ prehipertensi dari 7.695 subyek usia 30-59 tahun ${ }^{8}$.

Saat ini prehipertensi merupakan kondisi dengan risiko kardiovaskular di kemudian hari. Risiko yang berhubungan dengan prehipertensi dikaitkan dengan kecenderungan peningkatan tekanan darah seiring dengan peningkatan usia. Prehipertensi berhubungan dengan kecenderungan 3 kali lipat untuk mengalami hipertensi dan 2 kali lipat untuk mengalami kejadian kardiovaskular dibandingkan dengan tekanan darah normal ${ }^{5}$.

Prehipertensi dapat berkembang menjadi hipertensi pada usia yang lebih tua. Seperti hipertensi, prehipertensi cenderung untuk menjadi lebih berat seiring dengan berjalannya waktu. Progresifitas prehipertensi untuk menjadi hipertensi tergantung pada tingkat tekanan darah dan usia. Morbiditas untuk terjadinya penyakit jantung koroner dalam 4 tahun adalah $43 \%$ pada individu prehipertensi dengan tekanan darah yang lebih tinggi (130-139/85-89 $\mathrm{mmHg}), 20 \%$ pada prehipertensi dengan tekanan darah yang lebih rendah (120-129/80-84 $\mathrm{mmHg})$ dan $10 \%$ pada individu dengan tekanan darah normal. Morbiditas prehipertensi dalam 4 tahun untuk terjadinya hipertensi sebesar $42 \%$ pada usia $>65$ tahun dan $27 \%$ pada usia 35-64 tahun ${ }^{9}$. Dari studi epidemiologi yang kami lakukan perkembangan prehipertensi setelah 10 tahun menjadi hipertensi stage I sebanyak 152 (20\%) dan hipertensi stage II sebanyak 80 (11\%) pada usia 30-59 tahun.

Progresifitas terjadinya hipertensi dan prehipertensi dapat merupakan akumulasi beberapa faktor risiko. Odds Ratio (OR) prehipertensi yang berhubungan dengan faktor risiko tersebut lebih besar, yang berarti bahwa prehipertensi memiliki sebagian faktor risiko yang sama dengan hipertensi. Beberapa faktor risiko kardiovaskular tetap ada pada prehipertensi, dan akan berkembang menjadi hipertensi beberapa tahun kemudian ${ }^{9}$.

Pasien prehipertensi direkomendasikan untuk di follow up setiap tahun untuk mengantisipasi perkembangannya menjadi hipertensi. Rekomendasi ini berdasarkan temuan bahwa setelah 2 dan 4 tahun, berturut- 
turut $40 \%$ dan $63 \%$ prehipertensi berkembang menjadi hipertensi, dengan peningkatan risiko kejadian kardiovaskular. Hasil studi Frammingham Heart Study menunjukkan bahwa setelah 4 tahun, prehipertensi berkembang menjadi hipertensi sebanyak 39\% pada usia 35-64 tahun dan menjadi 53\% pada usia 65-94 tahun ${ }^{7}$. Studi kami mendapatkan prehipertensi berkembang menjadi hipertensi hanya sebanyak $31 \%$, hal ini diduga karena penelitian bukan di kota dan usia dibatasi 30-59 tahun.

Pada populasi umum, prehipertensi dapat diturunkan dengan modifikasi gaya hidup, namun seringkali tidak tercapai. Joint National Committee 7 (JNC 7) merekomendasikan manajemen prehipertensi dengan kontrol berat badan yang optimal (melalui diet dan latihan jasmani) (Chobanian et al., 2003). Konsumsi buah sirsak dapat menurunkan tekanan darah sistolik dan diastolik dalam waktu 6-12 minggu secara bermakna ${ }^{10}$.

Data epidemiologi menunjukkan bahwa terapi yang diperlukan untuk mencegah kejadian kardiovaskular pada pasien prehipertensi serupa dengan pada hipertensi stage I, bila kedua kelompok tersebut memiliki satu atau lebih faktor risiko yang sama ${ }^{5}$.

Tekanan darah sistolik $\geq 130 \mathrm{mmHg}$ atau tekanan darah diastolik $\geq 80 \mathrm{mmHg}$ direkomendasikan oleh ACC/AHA 2017 mendapat obat penurun tekanan darah sebagai tindakan pencegahan dan menghindari kejadian kardiovaskular ${ }^{4}$. Tujuan terapi prehipertensi adalah untuk mencegah terjadinya hipertensi dan mengurangi risiko PJK yang berhubungan dengan peningkatan tekanan darah ${ }^{7}$.

\section{KESIMPULAN}

Perkembangan prehipertensi setelah 10 tahun yang masih berusia 30-59 tahun pada studi epidemiologi di Mlati, Sleman, Yogyakarta adalah menjadi normal (normotensi) 24\%, tetap prehipertensi 44\%, menjadi hipertensi stage I sebanyak 20\% dan hipertensi stage II sebanyak 11\%. Secara keseluruhan dalam 10 tahun prehipertensi berkembang menjadi hipertensi sebanyak $31 \%$ sedangkan peneliti lain hasilnya lebih besar, hal ini diduga karena penelitian bukan di kota dan usia dibatasi 30-59 tahun.

Prehipertensi harus diturunkan walaupun bukan dengan obat farmakologi tetapi dengan perubahan gaya hidup seperti diet, olahraga, berhenti merokok, stop konsumsi alkohol, dan konsumsi buah sirsak sebagai penurun tekanan darah.

\section{KONFLIK}

Tidak ada conflict of interest.

\section{UCAPAN TERIMAKASIH}

Terimakasih kepada Tim Mlati Studi Group. 


\section{REFERENSI}

1. Ram CVS. Hypertension: A Clinical Guide. 1 edition. Boca Raton: CRC Press; 2014. 140 p.

2. Chobanian AV, Bakris GL, Black HR, Cushman WC, Green LA, Izzo JL, et al. The Seventh Report of the Joint National Committee on Prevention, Detection, Evaluation, and Treatment of High Blood Pressure: the JNC 7 report. JAMA. 2003;289(19):2560-72.

3. Julius S, Nesbitt SD, Egan BM, Weber MA, Michelson EL, Kaciroti N, et al. Feasibility of Treating Prehypertension with an Angiotensin-Receptor Blocker. New England Journal of Medicine. 2006;354(16):1685-97.

4. Whelton PK, Carey RM, Aronow WS, Casey DE, Collins KJ, Himmelfarb CD, et al. 2017 ACC/AHA/AAPA/ABC/ACPM/AGS/AP hA/ASH/ASPC/NMA/PCNA Guideline for the Prevention, Detection, Evaluation, and Management of High Blood Pressure in Adults: A Report of the American College of Cardiology/American Heart Association Task Force on Clinical Practice Guidelines. Hypertension. 2017 Jan 1;HYP.0000000000000065.

5. Egan BM, Nesbitt SD, Julius S. Prehypertension: should we be treating with pharmacologic therapy? Therapeutic advances in cardiovascular disease. 2008;2(4):305-314.

6. Ishikawa $\mathrm{Y}$, Ishikawa J, Ishikawa $\mathrm{S}$, Kario K, Kajii E. Progression from prehypertension to hypertension and risk of cardiovascular disease. Journal of Epidemiology. 2017 Jan 1;27(1):8-13.

7. Svetkey LP. Management of Prehypertension: Hypertension. 2005;45(6):1056-61.

8. Alatas H, Sja'bani M, Irijanto F, Prasanto H, Bawazier LA, Tomino Y. Serum asam urat pada populasi prehipertensi dibanding dengan populasi normal dan hipertensi di Mlati, Sleman, Yogyakarta, Indonesia. Indonesian Society of Nephrology and Hypertension. 2012;11.

9. Li H, Xu T, Tong W, Liu Y, Zhao L, Zhang Y. Comparison of Cardiovascular Risk Factors Between Prehypertension and Hypertension in a Mongolian Population, Inner Mongolia, China. Circulation Journal. 2008;72(10):166673.

10. Alatas H, Sja'bani M, Mustofa M, Mukti AG, Bawazier LA, Irijanto F, et al. The Effects Of Soursop Supplementation On Blood Pressure, Serum Uric Acid And Kidney Function In A Prehypertensive Population In Accordance With The 2017 ACC/AHA Guideline. Journal of Human Hypertension. 2019; in press. 


\section{TABEL DAN GAMBAR}

Tabel 1. Perkembangan Setelah 10 Tahun Prehipertensi Menjadi Normotensi, Tetap Prehipertensi, Hipertensi Stage I dan Stage II

\begin{tabular}{lr} 
Tekanan Darah & \multicolumn{1}{c}{ Jumlah } \\
\hline Normotensi & $183(25 \%)$ \\
Prehipertensi & $328(44 \%)$ \\
Hipertensi Stage I & $152(20 \%)$ \\
Hipertensi Stage II & $80(11 \%)$ \\
\multicolumn{1}{c}{ Total } & $743(100 \%)$ \\
\hline
\end{tabular}

\section{DAFTAR SINGKATAN}

ACC/AHA : American College of

Cardiology/American Heart Association

\begin{tabular}{ll}
\multicolumn{1}{c}{ BP } & : Blood pressure, tekanan \\
darah & : Cardiovascular disease, \\
CVD & : Senyakit kardiovaskular \\
JNC 7 & Senth Report of the \\
Joint National Committee & \\
PJK & : Penyakit jantung koroner
\end{tabular}

